\title{
Human PAF1 inhibition of HIV-1
}

\author{
Ana Guerrero Alonso*, Kelly Marno, William Ogunkolade, Julieta Diaz-Delfin, Eithne O'Sullivan, Áine McKnight \\ From Frontiers of Retrovirology: Complex retroviruses, retroelements and their hosts \\ Cambridge, UK. 16-18 September 2013
}

\section{Background}

The Polymerase II-Associated Factor 1 (PAF1) is a cellular protein with essential roles in transcription activation and repression, polyA tail cleavage, regulation of RNA polymerase elongation, regulation of gene expression, cell cycle control and mRNA quality surveillance[1]. It is part of a multicomponent complex together with other cellular proteins including SKI8, LEO1, CDC73, RTF1 and CTR9 [1]. We described that PAF1 has antiviral effect against HIV-1 that manifests early in the replication cycle [2]. Marazzi et al. described that PAF1 also inhibits influenza virus infection suggesting that PAF1 could have a broad antiviral activity [3]. Localisation of endogenous PAF1 is mainly in the nucleus but also in the cytoplasm. We propose three hypotheses: that PAF1 acts from the cytoplasm or the nucleus or both.

\section{Materials and methods}

To investigate a link between the antiviral function and cellular localisation of PAF1, human PAF1 mutants were engineered with altered nuclear localization signals. Wild type and mutant PAF1 constructs were characterised by confocal imaging, cellular fractionation and ability to inhibit HIV-1, 2 and SIV. Viral infectivity was measured by quantitative RT-PCR of early and late HIV-1 transcripts as well as focus forming units.

\section{Results}

Results describing the requirements for specific cellular localisations of PAF1 for viral inhibition will be presented.

\section{Conclusion}

Understanding the mechanism by which PAF1 modulates HIV-1 infection could unravel novel drug targets

Centre for Immunology and Infectious Disease, Blizard Institute, Barts and The London School of Medicine and Dentistry, Queen Mary University of London, London, Greater London, UK

\section{() Biomed Central}

(c) 2013 Alonso et al; licensee BioMed Central Ltd. This is an Open Access article distributed under the terms of the Creative Commons Attribution License (http://creativecommons.org/licenses/by/2.0), which permits unrestricted use, distribution, and reproduction in any medium, provided the original work is properly cited. not only against HIV-1 infection but possibly against other viruses.

Published: 19 September 2013

\section{References}

1. Tomson BN, Arndt KM: The many roles of the conserved eukaryotic Paf1 complex in regulating transcription, histone modifications, and disease states. Biochim Biophys Acta 2012.

2. Liu L, Oliveira NM, Cheney KM, Pade C, Dreja H, Bergin AM, Borgdorff V, Beach DH, Bishop CL, Dittmar MT, McKnight A: A whole genome screen for HIV restriction factors. Retrovirology 2011, 8:94.

3. Marazzi I, Ho JS, Kim J, Manicassamy B, Dewell S, Albrecht RA, Seibert CW Schaefer $U$, Jeffrey $\mathrm{KL}$, Prinjha RK, et al: Suppression of the antiviral

doi:10.1186/1742-4690-10-S1-P39

Cite this article as: Alonso et al.: Human PAF1 inhibition of HIV-1. Retrovirology 2013 10(Suppl 1):P39. response by an influenza histone mimic. Nature 2012, 483:428-433.
Submit your next manuscript to BioMed Central and take full advantage of:

- Convenient online submission

- No space constraints or color figure charges

- Immediate publication on acceptance

- Inclusion in PubMed, CAS, Scopus and Google Scholar

- Research which is freely available for redistribution Submit your manuscript at
www.biomedcentral.com/submit C BioMed Central
- Thorough peer review 